\title{
Upaya Meningkatkan Keterampilan Bertanya melalui Penerapan Pembelajaran berbasis Snowball Throwing
}

\author{
Putu Sukerni* \\ Guru SD Negeri 4 Kaliuntu, Bali, Indonesia
}

A R T I C L E I N F O

Article history:

Received 12 Maret

2018

Received in revised

form

23 Maret 2018

Accepted 12 April

2018

Available online 20

Mei 2018

Kata Kunci:

Model Pembelajaran

Snowball Throwing,

Keterampilan

Bertanya.

Keywords:

Snowball throwing

Learning Model,

Askin
A B S T R A K

Penelitian ini dilatar belakangi oleh rendahnya keterampilan bertanya siswa kelas I SD Negeri 4 Kaliuntu. Penelitian ini bertujuan untuk meningkatan keterampilan bertanya siswa dengan penerapan pembelajaran snowball throwing siswa kelas I di SD Negeri 4 Kaliuntu, Kecamatan Buleleng, Kabupaten Buleleng tahun pelajaran 2015/2016. Penelitian ini adalah penelitian tindakan kelas yang dilaksanakan dalam dua siklus. Setiap siklus terdiri atas tahap perencanaan, tindakan, observasi/evaluasi, dan refleksi. Subjek penelitian ini adalah siswa kelas I di SD Negeri 4 Kaliuntu, Kecamatan Buleleng, Kabupaten Buleleng tahun pelajaran 2015/2016 sebanyak 41 orang siswa. Pengumpulan data dalam penelitian ini dilakukan dengan menggunakan lembar observasi. Data yang dikumpulkan dianalisis dengan menggunakan metode analisis stasistik deskriptif dan anlisis deskriptif kuantitatif. Hasil penelitian menunjukan bahwa pembelajaran tematik dengan menggunakan pembelajaran snowball throwing dapat meningkatkan keterampilan bertanya siswa kelas I di SD Negeri 4 Kaliuntu, Kecamatan Buleleng, Kabupaten Buleleng tahun pelajaran 2015/2016. Pada siklus I rata-rata keterampilan bertanya siswa sebesar $58.2 \%$ pada kategori kurang dan meningkat menjadi $81.4 \%$ pada siklus II yang berada pada kategori baik.

\section{A B S T R A C T}

This research is based on the low skill of asking students in grade I SD Negeri 4 Kaliuntu. This study aims to increase the ability to ask questions of students with the implementation of learning model of snowball throwing of first grade students in SD Negeri 4 Kaliuntu, Buleleng sub-district, Buleleng regency year 2015/2016. This research was a classroom action research conducted in two cycles. Each cycle consists of planning, action, observation / evaluation, and reflection. The subjects of this study were the first grade students in SD Negeri 4 Kaliuntu, Buleleng District, Buleleng Regency in 2015/2016 school year as many as 41 students. Data collection in this research is done by using observation sheet. The data collected were analyzed using descriptive statistical analysis method and quantitative descriptive analysis. The result of the research shows that thematic learning using snowball throwing model can improve the ability to ask questions of first grade students in SD Negeri 4 Kaliuntu, Buleleng District, Buleleng Regency in the 2015/2016. In the first cycle, the students' skill question ws $58.2 \%$ in the less category and increased to $81.4 \%$ in cycle II which is in the good category. 


\section{Pendahuluan}

Keberhasilan proses pembelajaran merupakan muara dari seluruh aktivitas yang dilakukan guru dan siswa secara bersungguh-sungguh. Kurikulum 2013 merupakan kurikulum yang menuntut adanya pembelajaran inovatif dimana guru hanya berperan sebagai fasilitator dan motivator. Mutu pembelajaran di sekolah dapat dikembangkan dengan melibatkan peserta didik secara aktif sehingga terciptalah pembelajaran aktif. Pembelajaran aktif merupakan pembelajaran yang terpusat pada peserta didik. Belajar aktif membantu anak untuk mendengar, melihat, mengajukan pertanyaan tentang pelajaran tertentu, dan mendiskusikannya dengan yang lain. Pembelajaran aktif dapat dicirikan salah satunya dengan keaktifan siswa dalam bertanya dan menjawab pertanyaan dari guru selama berlangsungnya proses pembelajaran. Sesuai dengan Kurikulum 2013 SD pelaksanaan pembelajara tematik terpadu dan prosesnya dengan menggunakan pendekatan saintifik. Kegiatan bertanya merupakan salah satu aspek penting dari kurikulum 2013 yang berkaitan dengan pendekatan saintifik. Pendekatan Saintifik terdiri dari aspek mengamati, menanya, mengumpulkan informasi, mengolah informasi dan mengkomunikasikan.

Keterampilan bertanya merupakan bagian yang tidak terpisahkan dalam rangka meningkatkan kualitas proses dan hasil pembelajaran, yang sekaligus merupakan bagian dari keberhasilan dalam pengelolaan pembelajaran dan pengelolaan kelas. Menurut Taufik (2013) Keterampilan Bertanya adalah kemampuan dalam menggunakan berbagai jenis pertanyaan dan teknik bertanya untuk merangsang siswa untuk berpikir dalam menjawab pertanyaan yang diajukan guru. Yusmanah (2012) berpendapat bahwa keterampilan bertanya meupakan cara penyampaian suatu pelajaran melalui interaksi dua arah yaitu dari guru kepada siswa dan dari siswa kepada guru agar diperoleh jawaban kepastian materi melalui jawaban lisan guru atau siswa. "Bertanya atau mengajukan pertanyaan merupakan salah satu fungsi pokok bahasa selain fungsi lain seperti menyatakan pendapat, perasaan, mengajukan alasan, mempertegas pendapat dan sebagainya " (Royani,2014). Yuliana (2010) berpendapat bahwa keterampilan bertanya adalah ucapan atau pertanyaan yang dilontarkan guru yang menuntun respon atau jawaban dari peserta didik.

Observasi awal yang dilakukan di SD Negeri 4 Kaliuntu dilakukan dengan memperhatikan proses pembelajaran yang terjadi di kelas satu pada semester ganjil. Berdasarkan observasi yang dilakukan ditemukan bahwa keterampilan bertanya siswa tergolong rendah. Hal ini terlihat dari indikator keterampilan bertanya tidak terpenuhi mulai dari siswa jarang mengajukan pertanyaan kepada guru, siswa mengajukan pertanyaan dengan bahasa yang kurang tepat, siswa kurang percaya diri dalam mengajukan pertanyaan, dan banyak siswa yang meniru pertanyaan yang diajukan oleh temannya. Hal ini terjadi karena kemampuan guru untuk memancing peserta didik untuk bertanya masih kurang, latar belakang siswa yang tidak terbiasa untuk bertanya kepada orang dan siswa tidak tahu harus menanyakan apa karena siswa belum paham materi yang disampaikan oleh guru.

Berdasarkan permasalah tersebut maka guru perlu memberikan perhatian khusus dalam pemilihan pembelajaran yang tepat. Salah satu pembelajaran yang memungkinkan siswa berperan aktif dalam kegiatan pembelajaran sehingga dapat meningkatkan keterampilan bertanya siswa yaitu pembelajaran snowball throwing. Pembelajaran snowball throwing merupakan salah satu jenis pembelajaran yang dalam penerapannya terdapat kerja sama antar kelompok dalam pembelajaran dan saling ketergantungan antar siswa lainnya sekaligus melatih keterampilan bertanya siswa. Pembelajaran snowball throwing melatih siswa untuk lebih tanggap menerima pesan dari orang lain, dan menyampaikan pesan tersebut kepada teman dalam satu kelompok (Widodo, 2009). Dengan kegiatan pembelajaran yang dikemas dalam sebuah permainan yang menarik ini, akan membuat siswa merasa senang dalam mengikuti pelajaran sehingga dapat membangkitkan keinginan siswa untuk bertanya dan mencari tahu jawaban dari masalah yang siswa temukan sesuai dengan materi yang dibahas, yang pada akhirnya mengacu pada peningkatan keterampilan bertanya siswa.

Pembelajaran snowball throwing adalah pola atau rencana dalam pembelajaran yang dilakukan dengan cara melempar bola yang berisi pertanyaan dalam proses pembelajaran. "Pembelajaran snowball throwing merupakan pembelajaran yang dapat digunakan untuk memberikan konsep pemahaman materi yang sulit kepada siswa serta dapat digunakan untuk mengetahui sejauh mana pengetahuan dan kemampuan siswa dalam materi tersebut" (Farhan, 2011:4). "Pembelajaran snowball throwing melatih siswa untuk lebih tanggap menerima pesan dari orang lain, dan menyampaikan pesan tersebut kepada temannya dalam satu kelompok" (Widodo, 2009:7). Lemparan pertanyaan tidak menggunakan tingkat seperti pembelajaran talking stik, akan tetapi menggunakan kertas berisi pertanyaan yang diremas menjadi sebuah bola kertas lalu dilempar-lemparkan dari satu kelompok ke kelompok yang lain. Peran guru di sini hanya sebagai pemberi arahan awal mengenai topik pembelajaran, dan selanjutya penertiban terhadap jalanya pembelajaran. 
Pembelajaran snowball throwing termuat di dalam prinsip pendekatan kooperatif yang didasarkan pada lima prinsip, yaitu prinsip belajar siswa aktif (student active learning), belajar kerjasama (cooperative learning), pembelajaran partisipatorik, mengajar reaktif (reactive teaching), dan pembelajaran yang menyenangkan (joyfull learning). Di dalam pembelajaran snowball throwing strategi memperoleh dan pendalaman pengetahuan lebih diutamakan dibandingkan seberapa banyak siswa memperoleh dan mengingat pengetahuan tersebut Safitri (2011:12). Dari beberapa uraian di atas, dapat disimpulkan bahwa pembelajaran snowball throwing adalah pembelajaran yang dilakukan dengan pelemparan bola salju berisi pertanyaan yang ditulis oleh satu kelompok untuk dilempar kepada kelompok lain. Adapaun Langkah-langkah Penerapan Pembelajaran Snowbal Throwing adalah : a) Guru menyampaikan materi yang akan disajikan, b) Siswa membentuk yang terdiri dari 4 sampai 5 orang, dan menentukan satu siswa sebagai ketua kelompok, c) Masing-masing ketua kelompok mengambil materi yang diberikan oleh guru yang akan dibahas bersama kelompok masing-masing, d) Masing-masing ketua kelompok menjelaskan materi yang disampaikan oleh guru kepada temannya dalam kelompok, e) Masingmasing kelompok diberikan satu lembar kerja untuk menuliskan satu buah pertanyaan apa saja yang menyangkut materi yang sudah dijelaskan oleh ketua kelompok, f) Kemudian kertas tersebut dibuat seperti bola dan dilempar dari satu kelompok ke kelompok yang lain, g) Masing-masing kelompok menjawab pertanyaan yang terdapat pada bola yang dilemparkan oleh kelompok lain, dan kelompok lain memberikan tanggapan terhadap jawaban yang disampaikan oleh kelompok tersebut, h) Guru memberikan kesimpulan tentang materi yang telah dibahas, i) Guru mengadakan evaluasi, j) Penutup. (dimodifikasi dari Suprijono, 2009).

Wardhiana (2013) menyatakan Salah satu pembelajaran yang mampu mewujudkan situasi pembelajaran yang kondusif, aktif, kreatif, dan menyenangkan adalah dengan menerapkan pembelajaran kooperatif tipe snowball trhowing. Snowball throwing dapat diartikan melempar bola salju. Dalam pembelajaran snowball throwing, bola salju merupakan kertas yang berisi pertanyaan yang dibuat oleh siswa kemudian dilempar kepada temannya sendiri untuk dijawab (Jampel , 2017). Kusumayanti (2013) berpendapat bahwa snowball throwing merupakan salah satu jenis pembelajaran Cooperatif Learning dimana dalam pembelajaran ini terdapat kerjasama antar kelompok, saling ketergantungan antar siswa lainnya di dalam satu kelas. Sunistini (2011) Pembelajaran ini melatih siswa untuk lebih tanggap menerima pesan dari orang lain dan menyampaikan pesan tersebut kepada temannya dalam satu kelompok. Dewi (2013) menyatakan bahwa pembelajaran Snowball throwing yang dapat mengembangkan siswa untuk menyelesaikan masalah, bernalar, komunikasi, kepercayaan diri dan representasi Pada pembelajaran Snowball throwing memberikan pengalaman kepada siswa untuk mengembangkan keterampilan menyimpulkan isi berita atau informasi yang mereka peroleh dalam konteks nyata dan situasi yang kompleks (Antari, 2016). Lestari (2017) mengatakan bahwa pembelajaran snowball throwing membuat siswa lebih aktif tanpa sadar bahwa mereka sedang belajar, dengan adanya kreativitas. Pembelajaran snowball throwing melatih kesiapan siswa dalam menjawab pertanyaan yang diterima, saling memberikan pengetahuan antar siswa, dan memberikan kesenangan pada siswa karena mereka belajar tetapi dengan langkah-langkah yang membuat mereka serasa sedang bermain (Dewi,2017). Menurut Seriani (2017), Pembelajaran snowball throwing merupakan salah satu jenis pembelajaran cooperatif learning yang dalam penerapannya bertujuan memancing kreatifitas serta mengetahui sejauh mana pengetahuan dan kemampuan siswa dalam menguasai materi serta meningkatkan kerja sama antar kelompok dalam pembelajaran. "Pembelajaran Snowball throwing dapat menciptakan suasana yang menyenangkan dalam suatu proses belajar mengajar dan dapat membangkitkan motivasi siswa dalam belajar" (Simarmarta, 2018).

Setiap pembelajaran memiliki kelebihan dan kelemahan. Beberapa kelebihan pembelajaran snowball throwing tersebut sesuai dengan pendapat Safitri, (2011:15) yang menyatakan bahwa pembelajaran snowball throwing memiliki kelebihan yaitu sebagai berikut :(a) Melatih kesiapan siswa dalam merumuskan pertanyaan dengan bersumber pada materi yang diajarkan serta saling memberikan pengetahuan. (b) Siswa lebih memahami dan mengerti secara mendalam tentang materi pelajaran yang dipelajari. Hal ini disebabkan karena siswa mendapat penjelasan dari teman sebaya yang secara khusus disiapkan oleh guru serta mengarahkan penglihatan, pendengaran, menulis dan berbicara mengenai materi yang didiskusikan dalam kelompok. (c) Dapat membangkitkan keberanian siswa dalam mengemukakan pertanyaan kepada teman lain maupun guru. (d) Melatih siswa menjawab pertanyaan yang diajukan oleh temannya dengan baik. (e) Merangsang siswa mengemukakan pertanyaan sesuai dengan topik yang sedang dibicarakan dalam pelajaran tersebut. (f) Dapat mengurangi rasa takut siswa dalam bertanya kepada teman maupun guru. (g) Siswa akan lebih mengerti makna kerjasama dalam menemukan pemecahan suatu masalah. (h) Siswa akan memahami makna tanggung jawab. (i) Siswa akan lebih bisa menerima keragaman atau heterogenitas suku, sosial, budaya, bakat dan intelegensia. (j) Siswa akan terus termotivasi untuk meningkatkan kemampuannya. 
Lebih lanjut Farhan (2011:7) menyatakan bahwa kelebihan pembelajaran snowball throwing adalah "(a) melatih kesiapan siswa dalam mengikuti pelajaran, dan (b) saling memberikan pengetahuan".Safitri (2011:16) menjelaskan bahwa kelemahan pembelajaran dengan metode snowball throwing yaitu, "(a) terciptanya suasana kelas yang kurang kondusif, (b) adanya siswa yang bergantung pada siswa lain". Dengan demikian dapat disimpulkan bahwa kelemahan pembelajaran snowball throwing adalah sebagai berikut. (a) Terciptanya suasana belajar yang kurang kondusif. (b) Membutuhkan waktu yang relatif lama. (c) Pengetahuan yang diterima siswa hanya bergutat pada materi yang diajarkan pada saat itu saja. Farhan (2011:7) menyatakan bahwa kelemahan pembelajaran snowball throwing yaitu, "(a) pengetahuan tidak luas hanya berkutat pada pengetahuan sekitar siswa saja, (b) terciptanya suasana kelas yang kurang kondusif, dan (c) tidak efektif". Kelemahan-kelemahan yang terdapat pada penerapan pembelajaran snowball throwing dapat diminimalisasi dengan cara guru menyiasatinya dengan cara-cara tertentu sehingga tujuan dari pembelajaran dapat tercapai dengan baik.

\section{Metode}

Penelitian ini dilaksanakan di SD Negeri 4 Kaliuntu Kecamatan Buleleng Kabupaten Buleleng tahun pelajaran 2015/2016 di kelas 1 . Obyek penelitian ini adalah keterampilan bertanya siswa setelah penerapan Pembelajaran snowball throwing. Subjek penelitian ini adalah siswa kelas I semester genap SD Negeri 4 Kaliuntu tahun pelajaran 2015/2016. Jumlah siswa yang menjadi subjek penelitian adalah 41 orang. Jenis penelitian ini adalah penelitian tindakan kelas (PTK). Menurut Santyasa (dalam Tegeh, 2011:3) PTK didefinisikan sebagai suatu bentuk kajian yang bersifat reflektif oleh pelaku tindakanPenelitian ini dilaksanakan dalam dua siklus. Jumlah pertemuan tiap siklus adalah dua kali pertemuan untuk mengadakan pembelajaran.Tiap siklus terdiri dari empat tahapan yaitu: Perencanaan, Pelaksanaan, Observasi/Evaluasi, dan Refleksi. Penelitian ini dilaksanakan dalam 2 siklus. Setiap siklus dilaksanakan dalam 3 kali pertemuan yaitu 2 kali proses pembelajaran dan 1 kali tes akhir siklus. Data yang telah dikumpulkan dalam penelitian ini yaitu data tentang keterampilan bertanya siswa kelas I SD Negeri 4 Kaliuntu. Sudjana (2006:84) menyatakan "observasi atau pengamatan sebagai alat penilaian banyak digunakan untuk mengukur tingkah laku individu ataupun proses terjadinya suatu kegiatan yang diamati, baik dalam situasi yang sebenarnya maupun dalam situasi buatan". Lembar observasi ini digunakan untuk memperlihatkan pengelolaan pembelajaran Snowball throwing terhadap keterampilan bertanya siswa dalam pembelajaran. Dalam penelitian kelas ini yang bertindak sebagai pengamat sekaligus pengajar adalah peneliti. Sehingga yang mengamati keterampilan bertanya siswa dalam penerapan pembelajaran Snowball throwing terhadap pembelajaran adalah peneliti. Agung (2005:96) menyatakan bahwa, Metode analisis deskriptif kuantitatif adalah suatu cara pengolahan data yang dilakukan dengan jalan menyusun secara sistematis dalam bentuk angka-angka dan atau persentase mengenai keadaan suatu objek yang diteliti sehingga diperoleh kesimpulan umum. Kriteria yang digunakan untuk menunjukkan keberhasilan tindakan ini adalah terjadinya perubahan/peningkatan nilai keterampilan bertanya siswa dalam pembelajaran. Peningkatan nilai keterampilan secara rata-rata meningkat minimal sampai pada kategori "baik" dengan tingkat penguasaan (80 sampai dengan 89).

\section{Hasil dan Pembahasan}

\section{Hasil}

Data yang telah dikumpulkan dianalisis sesuai dengan teknik analisis data yang ditetapkan sebelumnya. Siklus 1 dibagi menjadi tiga kali pertemuan yaitu pertemuan 1 dilaksanakan pada Rabu 6 Januari 2016, pertemuan 2 dilaksanakan pada hari Kamis 7 Januari 2016 dan tes siklus I dilaksanakan pada hari Senin 11 Januari 2016. Nilai keterampilan bertanya siswa pada siklus I disajikan pada Tabel 1.

Tabel 1. Keterampilan Bertanya Siswa pada Siklus I

\begin{tabular}{cccc}
\hline No & Jumlah siswa & Rata- rata siklus 1 & Kategori \\
\hline 1 & 20 orang & 3 & Baik \\
2 & 16 orang & 2 & Cukup \\
3 & 5 orang & 1 & Kurang \\
\hline
\end{tabular}


Rata-rata nilai keterampilan bertanya siswa pada siklus I adalah 2,33. Rata-rata persentase nilai keterampilan bertanya siswa setelah diterapkan pembelajaran Snowball throwing pada siklus I adalah 58,2 \% dengan kategori "kurang".

Siklus II dibagi menjadi tiga kali pertemuan yaitu pertemuan 1 dilaksanakan pada hari Kamis, 14 Januari 2016, pertemuan 2 dilaksanakan pada hari Jumat, 15 Januari 2016, dan tes siklus dilaksanakan pada hari Rabu, 20 Januari 2016. Nilai keterampilan bertanya siswa pada siklus II disajikan pada tabel 2 di bawah ini.

Tabel 2. Nilai Keterampilan Bertanya Siswa Pada Siklus II

\begin{tabular}{|l|l|l|l|}
\hline No & Jumlah Siswa & Rata-rata & Kategori \\
\hline 1 & 22 orang & 4 & Sangat Baik \\
\hline 2 & 17 orang & 3 & Baik \\
\hline 3 & 2 orang & 2 & Cukup \\
\hline 4 & 0 & 1 & Kurang \\
\hline
\end{tabular}

Rata-rata nilai keterampilan bertanya siswa pada siklus II adalah 3,24. Pada siklus II, rata-rata persentase nilai keterampilan bertanya siswa mencapai 81,4 \% dengan kategori "baik".

Peningkatan nilai keterampilan bertanya setelah diterapkan pembelajaran Snowball throwing siklus I ke siklus II dapat dilihat pada gambar gafik batang di bawah ini:

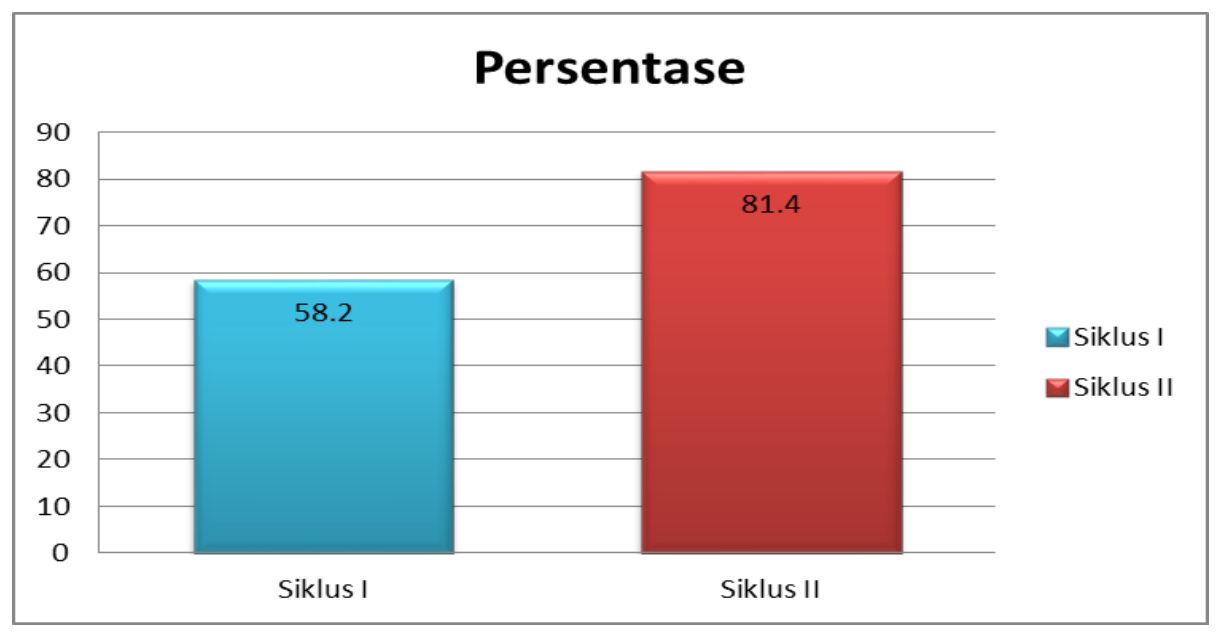

Gambar 1. Grafik perbandingan nilai keterampilan bertanya siswa pada siklus I dan siklus II

Berdasarkan analisis pada siklus I yaitu persentase keterampilan bertanya siswa mencapai 58,2\%. Presentase ini menunjukkan pada PAP Skala Lima tergolong kurang. Sedangkan pada Siklus II presentase keterampilan bertanya siswa mencapai 81,4\%. Persentase ini menunjukkan pada PAP Skala Lima tergolong baik. Jadi keterampilan bertanya dari siklus I ke siklus II terjadi peningkatan sebesar 23,2\%.

Hasil penelitian menunjukkan bahwa keterampilan bertanya siswa pada siklus I belum mencapai kreteria keberhasilan yaitu skor rata-rata keterampilan bertanya yang ditetapkan yaitu minimal 58,2\%. Hal ini disebabkan karena adanya beberapa kekurangan. Kekurangan-kekurangan pada siklus I adalah 1) siswa masih malu untuk mengajukan dan menjawab pertanyaan, 2) siswa belum mampu merespon atau menanggapi segala yang diajarkan dan ditanyakan guru, 3) kurang antusiasnya siswa dalam mengerjakan tugas yang diberikan oleh guru, 4) tidak adanya keterlibatan dari siswa maupun guru dalam menyimpulkan dan mengulangi pelajaran, 5) tidak ada semangat dari siswa untuk mempelajari materi yang diajarkan, 6) kurang optimalnya penggunaan media, dan 7) siswa belum terbiasa dengan penerapan model Snowball Throwing.

Berdasarkan kekurangan-kekurangan yang menyebabkan belum tercapainya kreteria keberhasilan yang ditetapkan, maka diadakan penyempurnaan pada siklus II yaitu 1) siswa dilibatkan secara langsung dalam proses pembelajaran, 2) dalam penyampaian materi guru menggunakan media gambar dan video pembelajaran agar siswa mampu memahami hal-hal yang bersifat abstrak, 3) guru lebih memahami dan mendalami bagaimana mengajar dengan menggunakan model Snowball throwing sehingga diharapkan 
lebih menegaskan dan memperjelas langkah-langkah pembelajaran agar siswa melakukan kegiatan sesuai dengan langkah-langkah pembelajaran Snowball Throwing.

Dengan melakukan upaya-upaya perbaikan tersebut, maka pada siklus II keterampilan bertanya siswa mengalami peningkatan dan telah mencapai kreteria keberhasilan yang ditetapkan. Hal ini terlihat jelas pada saat proses pembelajaran seperti 1) siswa sudah tidak malu mengajukan dan menjawab pertanyaan, 2) saling memberi selamat atau tepuk tangan kepada siswa lain agar menambah motivasi siswa, 3) sudah adanya keterlibatan dari siswa dan guru dalam membuat kesimpulan, 4) sudah adanya interaksi antara guru dan siswa, dan 5) hasil belajar dan keterampilan bertanya mengalami peningkatan.

\section{Simpulan dan Saran}

Penerapan pembelajaran snowball throwing di kelas I di SD Negeri 4 Kaliuntu dapat meningkatkan keterampilan bertanya siswa. Hal ini terbukti dari semakin meningkatnya skor rata-rata keterampilan bertanya siswa. Pada siklus I skor rata-rata untuk keterampilan bertanya siswa sebesar 58,2\% berada dalam kategori kuang, sedangkan rata-rata yang diperoleh siswa pada siklus II sebesar $81,4 \%$ berada dalam kategori baik. Ini berarti bahwa terdapat peningkatan keterampilan belajar siswa dari siklus I ke siklus II sebesar $23,2 \%$.

Berdasarkan hasil penelitian ini, peneliti dapat menyampaikan beberapa saran sebagai berikut: 1) Bagi siswa kelas I agar saat mengikuti proses pembelajaran dapat menyiapkan diri dengan baik sehingga lebih cepat memahami penjelasan dari guru. Jika hal ini dapat terlaksana, maka besar kecenderungan keterampilan bertanya akan meningkat, 2) Bagi guru SD Negeri 4 Kaliuntu disarankan agar menerapkan pembelajaran snowball throwing ini secara berkelanjutan karena memiliki keunggulan dan dapat meningkatkan keterampilan bertanya siswa. Melalui langkah-langkah pembelajaran yang tepat, diharapkan tercipta suasana yang menyenangkan dan tanpa ada perasaan tegang sedikit pun pada saat pembelajaran berlangsung. Selain itu, guru harus senantiasa memotivasi siswa untuk terus meningkatkan pengetahuan dengan cara lebih banyak membaca buku, bertanya, dan berdiskusi sehingga memudahkan siswa memahami informasi lainnya, 3) Bagi kepala Sekolah SD Negeri 4 Kaliuntu agar dapat membantu guru dalam menyediakan sumber-sumber belajar yang menunjang dalam pembelajaran, 4) Bagi peneliti lain agar mampu melaksanakan penelitian lebih lanjut dengan mengambil pokok bahasan lain sehingga diperoleh hasil yang lebih meyakinkan tentang penerapan pembelajaran snowball throwing..

\section{Daftar Rujukan}

Agung, A. A. G. (2005). Metodelogi Penelitian Pendidikan. Singaraja: Universitas Pendidikan Ganesha.

Agung, A. A. G. (2010). Pengantar Evaluasi Pendidikan. Singaraja: Universitas Pendidikan Ganesha.

Antari, N. M. D., Agustini, K., \& Divayana, D. G. H. (2016). Studi Komparatif Model Pembelajaran Talking Stick Dan Snowball Throwing Terhadap Hasil Belajar Teknologi Informasi Dan Komunikasi (Tik) Siswa Kelas Xi Sma Negeri 1 Seririt Tahun Ajaran 2015/2016. Jurnal Pendidikan Teknologi Dan Kejuruan, 13(2), 127-136. https://doi.org/10.23887/jptk-undiksha.v13i2.8521

Dewey Jonh. (2000). Berpikir adalah bertanya.

Dewi, M. P. (2013). Pengaruh Model Pembelajaran Snowball Throwing Terhadap Hasil Belajar IPA Siswa Kelas V SD di Gugus Sri Kandi Kecamatan Denpasar Timur. Mimbar PGSD, 1(1). Retrieved from https://ejournal.undiksha.ac.id/index.php/JJPGSD/article/viewFile/924/794

Dewi, N. P. K. R. (2017). Pengaruh Pembelajaran Snowball throwing Berbantuan Media Audiovisual Terhadap Penguasaan Kompetensi Pengetahuan IPA. Journal of Education Technology, 1(2), 191197.

Farhan. (2011). Pembelajaran Kooperatif Tipe Snowball Throwing.

Jampel, I. N., Widiana, I. W., Made, N. I., \& Juliantari, Y. (2017). Inovasi Pembelajaran Saintifik Dengan Snowball Throwing Dalam Proses Menanya Terhadap Hasil Belajar Siswa. Jurnal Ilmiah Sekolah Dasar, 1(2), 128-137. 
Kusumayanti , Dsk. Pt. Yulia, dkk. (2013). Pengaruh Pembelajaran Snowball throwing Berbantuan Media Konkret Terhadap Hasil Belajar Ipa Siswa Kelas V Di Gugus V Kecamatan Sukasada. Singaraja: Universitas Pendidikan Ganesha.

Lestari, Suniasih, D. (2017). Pengaruh Model Pembelajaran Snowball Throwing Berbasis Lagu- Lagu Anak Terhadap Kompetensi Pengetahuan PKn. Journal of Education Technology, 1(3), 163-168.

Mulyana, A. (2012). Kemampuan Bertanya Pada Siswa.

Nurkancana, W. dan S. (1990). Evaluasi Hasil Belajar. surabaya: Usaha Nasional.

Purnomo, M. (2011). Pengertian Keterampilan Bertanya.

Rahmawati, T. (2013). Pengelolaan Pembelajaran Tematik Terpadu. malang: PPPPTK BOE Malang.

Royani , M., B. M. (2014). Keterampilan Bertanya Siswa SMP Melalui Strategi Pembelajaran Aktif Tipe Team Quiz pada Materi Segi Empat. EDU-MAT Jurnal Pendidikan Matematika, 2(1), 22-28.

Safitri. (2011). Pembelajaran Snowball throwing untuk Meningkatkan Hasil Belajar Matematika.

Seriani, Ni Md., I. K. D. (2017). Penerapan Pembelajaran Snowball throwing Meningkatkan Hasil Belajar IPA Siswa Kelas VB SD No. 2 Dalung. Journal Education Action Research Undiksha, 1(3).

Simarmata, N. N. (2018). Upaya Meningkatan Hasil Belajar Siswa Dengan Menggunakan Pembelajaran Snowball Throwing. JIPP Undiksha, 2(1).

Sudjana, N. (2006). Penilaian Hasil Proses Belajar Mengajar. bandung: PT Remaja Rosdakarya.

Sunaryanti, F. (2011). Penerapan Pembelajaran Snowball throwing untuk Meningkatkan Aktifitas dan Hasil Belajar PKn Pada Siswa Kelas VIIC SMP N 7 Singaraja. Singaraja: Universitas Pendidikan Ganesha.

Sunistini Luh. (2011). Penerapan Model Snowball Throwing Berbantuan Media Sederhana Untuk Meningkatkanhasil Belajar Matematika Siswa Di Sd No 1 Petandakan. Singaraja: Universitas Pendidikan Ganesha.

Suprijono, A. (2009). Cooperative Learning (Teori dan Aplikasi Paikem). surabaya: Pustaka Pelajar.

suyadi. (2013). Strategi Pembelajaran Pendidikan Karakter. bandung: rosdakarya.

Taufik, R. (n.d.). Kemampuan guru menerapkan keterampilan bertanya pada pelajaran sosiologi di kelas xi sma islamiyah pontianak. pontianak: Universitas Tanjung Pura.

Tegeh. (2011). Penelitian Tindakan Kelas Sebagai Penelitian Peningkatan Kualitas Pembelajar. In Seminar Lokakarya, Jurusan Pendidikan Guru Sekolah Dasar, Universitas Pendidikan Ganesha, Singaraja 4 Juni 2011. Singaraja: Universitas Pendidikan Ganesha.

Tim Penyusun. (2003). Kamus Pelajar. Jakarta: Pusat Bahasa: Departemen Pendidikan Nasional.

Trianto. (2007). Model-pembelajaran Inovatif Berorientasi Kontrufistik. surabaya: prestasi pustaka.

Uno, H. B. (2006). Orientasi baru dalam psikologi belajar. Bumi Aksara. Jakarta: Bumi Aksara.

Wardhiana, I. K. S., Asri, I. G. A. A. S., \& Suniasih, N. W. (2013). Penerapan Model Pembelajaran Kooperatif Tipe Snowball Throwing Untuk Meningkatkan Keaktifan Dan Hasil Belajar Pkn Kelas V Sd Negeri 1 Bungbungan. Singaraja: Universitas Pendidikan Ganesha. 
Widodo, R. (2009). Pembelajaran Snowball Throwing.

Yuliana, L. (2010). Keterampilan Bertanya Guru dalam Mengelola Proses Belajar Mengajar.

Yusmanah. (n.d.). Peningkatan Keterampilan Bertanya dengan Menggunakan Metode Penemuan Terbimbing dalam Pembelajaran Matematika. pontianak: Universitas Tanjung Pura. Retrieved from http://jurnal.untan.ac.id/index.php/jpdpb/article/view/693 